\title{
СЛАВКОВСКОЕ СОТРУДНИЧЕСТВО
}

\begin{abstract}
Аннотация. В статье рассматриваются наиболее важные этапы становления нового формата иентральноевропейского сотрудничества с участием Австрии, Словакии и Чехии. Автор анализирует причины его появления, которые, по его мнению, кроются в политическом диссонансе, проявившемся в политической жизни Вишеградской четвёрки в последние годbl, а также в позиции Австрии, стремящейся вернуться в традиционный для неё культурно-исторический регион для построения новой формы регионального взаимодействия на фоне противоречий, раздирающих Европейский союз.
\end{abstract}

Ключевые слова: Австрия, Чехия, Словакия, Славковское взаимодействие, региональное сотрудничество.

В январе 2015 г. в Центральной Европе появился новый формат сотрудничества с участием Чешской Республики, Словакии и Австрии - «S3». 29 января 2015 г., в чешском городе Славков премьер-министр Чехии Богуслав Соботка и премьер-министр Словакии Роберт Фицо вместе с канцлером Австрии Вернером Файманом подписали так называемую «Славковскую декларацию». Следует отметить, что место для проведения данной встречи было выбрано не случайно - город Славков-у-Брна, известный ранее как Аустерлиц, возле которого в 1805 г. состоялось сражение, считающееся триумфом дипломатического и военного гения Наполеона. Славковская декларация стала результатом чешско-австрийского сближения, символическим началом которого послужил визит премьер-министра Чехии в Вену в июне 2014 г. и ответный визит его австрийского коллеги в Прагу спустя месяц. Это дало толчок серии интенсивных рабочих встреч между высшими чиновниками двух стран, включая министров и глав ведомств.

Во втором полугодии 2014 г. Богуслав Соботка несколько раз общался с премьер-министром Словакии Робертом Фицо. Существует предположение, что именно чешская сторона вследствие своей заинтересованности в новых энергетических и инфраструктурных проектах предложила Братиславе участие в данной инициативе. Декларация была разработана в то время заместителем министра иностранных дел Чехии, бывшим директором Пражского института международных отношений, Петром Друлаком. Согласно его планам, формат S3 должен был дополнить деятельность Вишеградской группы так же, как сотрудничество Польши со странами Балтийского региона усиливает работу группы на центральноевропейском уровне. В своих публикациях и интервью он и раньше указывал на необходимость «нового старта» в отношениях с южным соседом Чехии. Его видение австро-чешского альянса, однако, более амбициозно, чем то, что обсуждалось в Славкове. П. Друлак считал, что тесное сотрудничество между двумя странами должно было стать отправной точкой для расширения регионального альянса на другие государства, такие как Словения и Хорватия ${ }^{1}$. Это позволило бы Пра-

(C) Русакова Мария Юрьевна - научный сотрудник Отдела исследований Центральной и Восточной Европы Института Европы РАН. Aдрес: 125009, Россия, Москва, ул. Моховая, д. 11, стр. 3. E-mail: mjrusakova@gmail.com.

DOI: http://dx.doi.org/10.15211/vestnikieran620183641

${ }^{1}$ Diplomat Drulák: Méně Británie, více Rakouska. URL: https://echo24.cz/a/wmz4H/diplomat-drulak-mene-britanie- 
ге увеличить свой вес на Западных Балканах, в регионе, который, благодаря тесным исторических связям, своему геополитическому значению, а также обширным экономическим и человеческим контактам, является одним из приоритетных для внешней политики Чехии.

Согласно декларации, новый формат направлен не только на укрепление сотрудничества между Чехией, Словакией и Австрией. Одной из его главных целей на европейском уровне является интенсификация экономики и повышение уровня занятости ${ }^{1}$.

Таким образом, главной задачей S3 стало создание новой платформы регионального сотрудничества между Словакией, Чехией и Австрией, где основное внимание уделяется как совместным проектам, так и взаимному обмену информацией, координации позиций по текущей ситуации в Европейском союзе.

Действительно, Словакия, Чехия и Австрия исторически весьма близки. Между ними существует множество общих областей для потенциального сотрудничества. Так, например, согласно декларации, одним из приоритетных направлений является совместное развитие транспортной и энергетической инфраструктуры этих стран. Между Чешской Республикой и Австрией нет автомагистрали, отсутствует соединительный трубопровод между их газотранспортными сетями. Планы строительства нефтепровода между государствами также были приостановлены. В чешско-словацком же диалоге регулярно поднимается вопрос о необходимости модернизации автомагистрали D2 между Центральной и Северной Моравией и соседними регионами Словакии. Ещё одним возможным направлением сотрудничества является интеграция газовых рынков и создание общей инфраструктуры и системы её регулирования.

Другим фактором, который способствовал запуску австрийско-чешско-словацкого сотрудничества, стало то, что во главе правительств этих стран находились лидеры социал-демократических партий, входящих в Партию европейских социалистов (ПЕС). Общность политических интересов, таким образом, повлияла на круг стран, приглашённых к участию, и стала косвенным объяснением того, почему Венгрия не вошла в новый формат сотрудничества. Выступая на пресс-конференции после подписания декларации, Богуслав Соботка особо отметил идеологическую близость партнёров и приверженность социальным реформам в Европейском союзе как одну из ключевых причин создания треугольника $\mathrm{S}^{2}$.

В Славкове было решено, что главы правительств будут встречаться в подобном формате каждый год, а ежедневная работа будет координироваться трёхсторонней рабочей группой на уровне заместителей министров иностранных дел ${ }^{3}$. Были обозначены и приоритетные области сотрудничества на ближайший год: инфраструктура, социальная политика, приграничное сотрудничество, отношения с западно-балканскими государствами, а также странами, входящими в Восточное партнёрство. Премьер-министры согласились с необходимостью повысить осведомлённость общественности о прогрессе в области европейской интеграции и её конкретных достижениях. Кроме того, они обсудили вопросы, связанные с инвестиционной политикой Европейской комиссии, подчеркнув её ценность для роста и укрепления конкурентоспособности европейской экономики. Находясь под впечатлением от произошедших незадолго до этого терактов во Франции, главы правительств согласились с необходимостью принятия мер, устраняющих угрозу таких инцидентов в будущем. По их заявлению, для этого

\footnotetext{
vice-rakouska (accessed 26.12.2018).

Austerlitz Declaration. URL: https://www.vlada.cz/assets/media-centrum/aktualne/Austerlitz-Declaration.pdf (accessed 26.12.2018).

The Slavkov Triangle: A Rival to the Visegrad Group? URL: https://www.pism.pl/files/?id_plik=19252 (accessed 26.12.2018).

Austerlitz Declaration. URL: https://www.vlada.cz/assets/media-centrum/aktualne/Austerlitz-Declaration.pdf (accessed 26.12.2018).
} 
необходимо провести пересмотр общей контртеррористической стратегии ЕС. Предотвращение и всеобъемлющее решение связанных с миграцией проблем должно стать важной частью этой стратегии ${ }^{1}$.

Второй саммит в Славковском формате прошёл 22 июня 2017 г. в чешском Брно. Главной его темой стало детальное обсуждение плана работы на 2017 г. Он включил в себя конкретное сотрудничество между Австрией, Чехией и Словакией в пяти областях: транспортная инфраструктура, образование, энергетическая безопасность, индустрия 4.0 и отношения c $\mathrm{EC}^{2}$

Следующая встреча глав правительств трёх стран состоялась уже через 2 месяца, 23 августа в австрийском Зальцбурге, и привлекла к себе большое внимание политических кругов Евросоюза. Помимо премьер-министра Чехии Богуслава Соботки, канцлера Австрии Кристиана Керна и премьер-министра Словакии Роберта Фицо на встрече также присутствовал президент Франции Эммануэль Макрон. Встреча в Зальцбурге стала частью его так называемого «стратегического турне» по странам ЕС для общих консультаций между государствами-членами о будущем Союза и для призыва к сплочению и единству перед лицом международных вызовов. Для Э. Макрона саммит S3 стал важной политической площадкой ещё и потому, что его предложения по реформе Директивы о командированных работниках - одного из его предвыборных обещаний - были раскритикованы и оспорены именно в Центральной Европе. В то время как Австрия, занимающая четвёртое место в Европейском союзе по числу принимаемых командированных работников, поддержала инициативу Макрона, Польша и Венгрия, которые не присутствовали в Зальцбурге, выступили резко против предложенной Францией поправки к Директиве ${ }^{3}$. Таким образом, чтобы обсудить данную проблему, Макрон намеренно выбрал формат S3, а не V4, несмотря на то, что большинство командированных работников прибывают в Западную Европу именно из Польши. Встреча французского президента с чешским и словацким премьер-министрами (без Польши и Венгрии) также может быть расценена как своеобразная попытка принизить роль V4 на политической арене ЕС.

Помимо реформы Директивы о командированных работниках участники встречи обсудили будущее Европейского союза: экономическое и социальное сближение центральноевропейских стран, вопросы промышленности, безопасности и миграции. Присутствующие согласились с тем, что Евросоюз должен усилить защиту внешних границ, однако вопрос о системе обязательного приёма беженцев странами ЕС в очередной раз подтвердил различие позиций Чехии и Словакии, с одной стороны, и Франции, с другой ${ }^{4}$.

4 октября 2018 г. в чешском городе Кромержиж состоялась встреча председателя Палаты депутатов Чехии Радека Вондрачека с его словацким и австрийским коллегами Андреем Данко и Вольфгангом Соботкой. По итогам встречи ими была подписана декларация, направленная на углубление сотрудничества трёх парламентов. Так, председатели парламентов договорились о двусторонних визитах и стажировках своих сотрудников. Также представители

\footnotetext{
${ }^{1}$ The Prime Ministers of Austria, the Czech Republic, and Slovakia meet in Slavkov (Austerlitz) to establish a new format of regional cooperation. URL: https://www.vlada.cz/en/media-centrum/aktualne/the-prime-ministers-of-austria-the-czech-republic--and-slovakia-meet-in-slavkov-austerlitz-to-establish-a-new-format-of-regional-cooperation-126356/ (accessed 26.12.2018).

2 Prime Minister Sobotka debated in Brno with premiers of Austria, Mr. Kern, and Slovakia, Mr. Fico. URL: https://www.vlada.cz/en/media-centrum/aktualne/prime-minister-sobotka-debated-in-brno-with-premiers-of-austria-mr--kern--and-slovakia--mr--fico-157944/ (accessed 26.11.2018).

PISM Spotlight: The French President's Meeting with the Heads of Government of the Slavkov Triangle. URL: https://www.pism.pl/publications/spotlight/no-46-2017?wersja_pelna=1\# (accessed 26.11.2018).

${ }^{4}$ The prime ministers dealt in the Slavkov format on economic and social convergence, safety and migration. URL: https://www.vlada.cz/en/media-centrum/aktualne/the-prime-ministers-dealt-in-the-slavkov-format-on-economic-andsocial-convergence--safety-and-migration-159201/tmplid-81/ (accessed 26.11.2018).
} 
трёх стран обязались работать над проблемой повышения доверия граждан к демократическим процессам и европейской интеграции с целью устранить «недоразумения», которые в последнее время происходят в Европе ${ }^{1}$. Помимо этого, на встрече обсуждались вопросы нелегальной миграции и отношения с государствами - соседями Славковского треугольника. По словам В. Соботки, необходимо помочь балканским странам, которые стремятся к вступлению в Европейский союз ${ }^{2}$. Австрия уже приступила к более тесному сотрудничеству с Сербией, Черногорией и Албанией.

Что касается дальнейших перспектив Славковского сотрудничества, то следует отметить, что ещё в ходе подготовки к первой встрече чешское правительство заявило о том, что создание нового формата взаимодействия с Австрией и Словакией не является альтернативой Вишеградской группе, поскольку оно будет касаться сугубо регионального и трансграничного измерения сотрудничества и не претендует на представительство Центральной Европы за её пределами. Несмотря на это, в ходе встречи в Славкове премьер-министры приняли решение о том, что до заседания Европейского совета в феврале всё же состоится телеконференция, которая поможет скоординировать их позиции.

Тем не менее первая встреча S3 с лидером Франции в 2017 г. показала, что для Чешской Республики и Словакии Славковское сотрудничество в некоторых сферах всё же может быть альтернативой V4. Нельзя исключать, что новый формат «S3+» потенциально рассматривается этими странами как более эффективная платформа для контактов с третьими странами нежели «V4+». Во всяком случае, она может быть удачной запасной площадкой в случае необходимости дистанцироваться от других партнёров по V4 - Польши и Венгрии. Кроме того, августовский саммит 2017 г. был особенно важен для Чехии, т.к. она использовала эту встречу на высшем уровне для получения статуса наблюдателя на совещаниях Еврогруппы ${ }^{3}$.

В целом можно заключить, что создание Славковского треугольника, безусловно, добавило напряжённости в отношения внутри Вишеградской четвёрки. Усиливающиеся дебаты по поводу будущего Европейского союза начали выявлять расхождения во мнениях внутри самой V4. Возникающие новые формы регионального сотрудничества, такие, как S3 и TSI, могут сигнализировать о попытках изменить соотношение сил в регионе, однако остаётся вопрос - до какой степени? Ведь и у Славковского формата есть уязвимые места. К слабым сторонам Славковского «треугольника» следует отнести его недостаточно глубоко проработанную повестку дня (заявленный спектр деятельности слишком широк и дублирует некоторые Вишеградские и европейские инициативы), а также тот факт, что интересы стран-участниц и в этом составе не всегда совпадают. Славковская декларация не раскрывает многое об этой «новой структуре для расширения сотрудничества в добрососедских и европейских делах», но довольно расплывчато заявляет, что она должна способствовать «повышению осведомлённости общественности об общих интересах, доверии к региональному сотрудничеству и европейской интеграции» ${ }^{4}$. Собственно, об этом же говорится и в официальных документах других региональных структур.

\footnotetext{
${ }^{1}$ Kromeriz Declaration to deepen cooperation in Central Europe. URL:http://www.psp.cz/en/sqw/cms.sqw?z=11844 (accessed 26.11.2018).

${ }^{2}$ Ibid.

3 Czechs in favour of deeper integration, but shun the euro. URL: https://www.euractiv.com/section/centraleurope/news/czechs-in-favour-of-deeper-integration-but-shun-the-euro-per-integration-but-shun-the-euro/ (accessed 26.11.2018).

${ }^{4}$ Was Visegrad defeated in Slavkov? URL: https://visegradinsight.eu/was-visegrad-defeated-in-slavkov11022015/ (accessed 27.11.2018).
}

Научно-аналитический вестник ИЕ РАН, 2018, №6 


\section{Список литературы}

Вишеградская четвёрка в Европейском союзе: дилеммы конвергенции / под ред. Л.Н. Шишелиной // М.: Ин-т Европы РАН, 2017. - 140 с.

Центральная Европа: политический портрет на фоне 100-летия / под ред. Л.Н. Шишелиной, М.В. Ведерникова // М.: Ин-т Европы РАН, 2018. - 240 с.

\section{References}

Central'naya Evropa: politicheskij portret na fone 100-letiya / pod red. L.N. Shishelinoj, M.V. Vedernikova // M.: In-t Evropy RAN, 2018. - 240 s.

Hendrych L. zechs in favour of deeper integration, but shun the euro, EURACTIV.cz. 25.08.2017. URL: https://www.euractiv.com/section/central-europe/news/czechs-in-favour-ofdeeper-integration-but-shun-the-euro-per-integration-but-shun-the-euro/ (accessed 26.11.2018).

Jurczyszyn L., Ogrodnik L. PISM Spotlight: The French President's Meeting with the Heads of Government of the Slavkov Triangle, PISM. 25.08.2017. URL: https://www.pism.pl/ publications/spotlight/no-46-2017?wersja_pelna=1\# (accessed 26.11.2018).

Kaiser D. Diplomat Drulák: Méně Británie, více Rakouska, Echo24.cz. 22.06.2014. URL: https://echo24.cz/a/wmz4H/diplomat-drulak-mene-britanie-vice-rakouska (accessed 26.12.2018).

Kałan D. The Slavkov Triangle: A Rival to the Visegrad Group? PISM. 16.02.2015. URL: https://www.pism.pl/files/?id_plik=19252 (accessed 26.12.2018).

Kromeriz Declaration to deepen cooperation in Central Europe, Chamber of Deputies of the Czech Republic. 04.10.2018. URL: http://www.psp.cz/en/sqw/cms.sqw?z=11844 (accessed 26.12.2018).

Prime Minister Sobotka debated in Brno with premiers of Austria, Mr. Kern, and Slovakia, Mr.Fico, Government of the Czech Republic. 22.06.2017. URL: https://www.vlada.cz/en/mediacentrum/aktualne/prime-minister-sobotka-debated-in-brno-with-premiers-of-austria--mr--kern--andslovakia--mr--fico-157944/ (accessed 26.12.2018).

Schneider J. (2015) Was Visegrad defeated in Slavkov? Visegrad Insight. 11.02.2015. URL: https://visegradinsight.eu/was-visegrad-defeated-in-slavkov11022015/ (accessed 27.11.2018).

The Prime Ministers of Austria, the Czech Republic, and Slovakia meet in Slavkov (Austerlitz) to establish a new format of regional cooperation, Government of the Czech Republic. 29.01.2015. URL: https://www.vlada.cz/en/media-centrum/aktualne/the-prime-ministers-of-austria--the-czechrepublic--and-slovakia-meet-in-slavkov-austerlitz-to-establish-a-new-format-of-regionalcooperation--126356/ (accessed 26.11.2018).

The prime ministers dealt in the Slavkov format on economic and social convergence, safety and migration, Government of the Czech Republic. 23.08.2017. URL: https://www.vlada.cz/en/mediacentrum/aktualne/the-prime-ministers-dealt-in-the-slavkov-format-on-economic-and-socialconvergence--safety-and-migration-159201/tmplid-81/ (accessed 26.11.2018).

Vishegradskaya chetvyorka $\mathrm{v}$ Evropejskom soyuze: dilemmy konvergencii / pod red. L.N. Shishelinoj // M.: In-t Evropy RAN, 2017. - 140 s. 


\section{Slavkov Cooperation}

Author. Mariya Rusakova, Research Associate, Department of Central and Eastern European studies, Institute of Europe, Russian Academy of Sciences. Address: 11-3, Mokhovaya str., Moscow, Russia, 125009. E-mail: mjrusakova@gmail.com.

Abstract. The article considers the most important stages in the formation of a new format of Central European cooperation with the participation of Austria, Slovakia and the Czech Republic. The author analyzes the reasons for its appearance, which, in her opinion, lie in the political dissonance manifested in the political life of the Visegrad Four in recent years as well as in the position of Austria, seeking to return to its traditional cultural and historical region in order to build a new form of regional cooperation against the backdrop of contradictions tearing at the European Union.

Keywords: Austria, Czech Republic, Slovakia, Slavkov cooperation, regional cooperation

DOI: http://dx.doi.org/10.15211/vestnikieran620183641 